\title{
Schematic cost estimating model for super tall buildings using a high-rise premium ratio
}

\author{
Jong-San Lee, Hyun-Soo Lee, and Moon-Seo Park
}

\begin{abstract}
Super tall building construction involves considerable financial uncertainty due to its potentially low returns despite high investments. To reduce this financial risk, it is crucial to accurately estimate the schematic construction cost of such projects. However, traditional cost estimating practices (TCEP) are not effective at predicting the cost of schematic design phase design alternatives that involve the change in the number of building stories. To address these issues, this research proposes a schematic cost estimating model (SCEM). The SCEM estimates the schematic construction cost of super tall building alternatives using a simulation mechanism that considers variation in the number of building stories (i.e., \pm 5 , $\pm 10, \pm 15, \pm 20$ stories). First, the limitations of the traditional practices are identified. Then, three pilot alternatives (i.e., one schematic design and two design alternatives) are designed and estimated in detail. Next, cost simulation mechanism is constructed based on the relationships between design scale, material quantity, unit cost rate, and construction cost. In addition, after determining which dominant factors affect construction cost when the number of building stories changes, the high-rise premium ratio and its theoretical framework are introduced. This ratio is used to identify the productivity ratios of super tall buildings and to simulate construction cost as the building design changes. Finally, the SCEM is validated through a case study of an actual super tall building. It is found that schematic construction cost increases as the unit cost rate rises due to a low productivity ratio in the case of a higher number of building stories. Conversely, this cost decreases as the unit cost rate goes down due to a high productivity ratio in the case of a lower number of building stories. Ultimately, the SCEM is developed to support effective decision-making during the schematic design phase.
\end{abstract}

Key words: super tall buildings, high-rise building, quantity, cost estimation, schematic cost estimating model (SCEM), high-rise premium ratio.

Résumé : La construction des immeubles de très grande hauteur implique une incertitude financière considérable en raison de son rendement potentiellement faible malgré de forts investissements en capital. Pour réduire ce risque financier, il est important d'estimer précisément les coûts schématiques de construction de tels projets. Toutefois, les pratiques traditionnelles d'estimation des coûts ne sont pas efficaces pour prédire le coût schématique d'alternatives de conception pour la phase de conception qui impliquent un changement du nombre d'étages de l'immeuble. Pour aborder ces questions, la présente recherche propose un modèle schématique d'estimation des coûts. Ce modèle estime le coût schématique de construction d'alternatives aux immeubles de très grande hauteur en utilisant un mécanisme de simulation qui tient compte de la variation dans le nombre d'étages de l'immeuble (c.-à-d. $\pm 5, \pm 10, \pm 15, \pm 20$ étages). Premièrement, les limites des pratiques traditionnelles sont identifiées. Puis trois options pilotes (une conception schématique et deux alternatives de conception) sont conçues et estimées en détail. Ensuite, le mécanisme de simulation des coûts est élaboré en se basant sur les relations entre l'échelle de conception, la quantité de matériel, le taux de coût unitaire et le coût de construction. De plus, après avoir déterminé les facteurs dominants qui affectent le coût de construction lorsque le nombre d'étages de l'immeuble change, le coefficient de base des immeubles de grande hauteur, et son cadre théorique, sont présentés. Ce coefficient est utilisé pour identifier les ratios de productivité des immeubles de très grande hauteur et pour simuler le coût de construction lors de changements à la conception des immeubles. Finalement, le modèle schématique d'estimation des coûts est validé en utilisant une étude de cas d'un immeuble réel de très grande hauteur. Il a été conclu que le coût schématique de construction augmente avec l'augmentation du taux de coût unitaire en raison du faible ratio de productivitédans le cas d'un nombre plus élevé d'étages d'un immeuble. Réciproquement, ce coût diminue lorsque le taux de coût unitaire diminue en raison d'un fort rapport de productivité dans le cas d'un immeuble ayant moins d'étages. Enfin, le modèle schématique d'estimation des coûts est développé pour soutenir un processus décisionnel efficace durant la phase de conception schématique.

Mots-clés : immeubles de très grande hauteur, immeuble de grande hauteur, quantité, estimation des coûts, modèle schématique d'estimation des coûts, coefficient de base des immeubles.

[Traduit par la Rédaction]

Received 29 August 2009. Revision accepted 22 February 2011. Published at www.nrcresearchpress.com/cjce on 12 May 2011.

J.-S. Lee, H.-S. Lee, and M.-S. Park. Department of Architecture, Seoul National University, Seoul, 151-742, Korea.

Corresponding author: Jong-San Lee (e-mail: leejongsan@naver.com).

Written discussion of this article is welcomed and will be received by the Editor until 30 September 2011. 


\section{Introduction}

Super tall building construction is often a risky venture, as these projects can yield low profits despite billion dollar investments. To minimize risk, accurate cost estimates must be established, particularly during the schematic design stage. These early cost estimates are vital for decision-making pertaining to asset development strategies, potential project screening, and resource commitment for further project development among others (Oberlender and Trost 2001).

However, most conventional cost estimating approaches can often determine construction cost of super tall building alternatives after the design development (DD) documents are completed. As well, because these methods do not incorporate a cost estimate simulation mechanism, they cannot effectively estimate the cost of design alternatives during the schematic design phase. Consequently, if there is discrepancy between expected construction cost and the project budget, costly and time-consuming DD phase re-design work must be repeated.

To address these issues, a schematic cost estimating model (SCEM) is proposed that can estimate the cost of super tall building alternatives. The research process is as follows. First, the limitations of the traditional practices are described. Second, to implement a simulation mechanism and productivity ratio, three pilot alternatives (i.e., one schematic design and two design alternatives) are designed and estimated in detail. Then, cost simulation mechanism is developed by analyzing the relationships among design scale, material quantity, unit cost rate, and construction cost. Furthermore, by determining which factors predominantly affect construction cost and how they impact cost as the number of building stories varies, the theoretical framework of the high-rise premium ratio is constructed. These simulation mechanisms using the high-rise premium ratio are subsequently applied to estimate the respective construction costs of design alternatives as the number of building stories (i.e., $\pm 5, \pm 10$, $\pm 15, \pm 20$ stories) changes. Finally, the SCEM is validated through a case study of an actual project.

In terms of research scope, this study examines diverse distinctive features of five existing super tall buildings (see Table 1). The proposed SCEM is designed to provide owners with an accurate anticipated project cost; this will assist them in determining project feasibility and planning further project development.

\section{Traditional cost estimating practices}

Traditionally, construction cost of super tall buildings is estimated by measuring material quantities from design development (DD) drawings, and then sequentially local unit costs (i.e., material unit cost, equipment unit cost, and labor unit cost) can be applied to material quantities. These unit costs are obtained from sub-contractors, suppliers, and vendors through tender invitations and in-house cost databases. Moreover, for a better analytical approach, various statistical and mathematical methods have been applied to construction cost estimating in the early stages. Touran (2003) developed a probabilistic model for the calculation of project cost contingency by considering the expected number of changes and the average cost of change. As well, Shaheen et al. (2007) explores an alternate approach to range estimating using fuzzy set theory and Monte Carlo simulation in schematic cost estimating. Jrade and Alkass (2007) outlined a computer-integrated methodology used for a conceptual cost estimating. Sonmez (2008) proposed an integrated method for conceptual cost estimating by integrating the advantages of parametric and probabilistic estimating techniques. Yu and Skibniewski (2010) described an adaptive neurofuzzy inference system including a conceptual cost estimation method and principal items ratio estimation method. This method estimates construction cost by separating unit prices and quantities of the required resources for a cost item. These conventional approaches and advanced methods have contributed to improving the accuracy in cost estimating but they have the following limitations: (1) if the owner requires design alternatives due to discrepancy between estimated construction cost and the project budget, it is difficult to estimate the cost of these alternatives without reiterating the re-design work of the DD phase; and (2) significantly, the conventional methods do not perform cost simulation mechanism according to a changing productivity ratio.

Although many researchers have tried to predict the trends of changing labor productivity using historical data by applying quantitative approaches such as time-series analysis and artificial neural network (Portas and AbouRizk 1997; Abdelhamid and Everett 1999; Song and AbouRizk 2008; and Hwang and Liu 2010), there are some difficulties to reflect predicted value of labor productivity in cost estimating of high-rise building projects because vertical factors were not taken into consideration. Meanwhile, during the development of the SCEM, the owner group of the case project requested three pilot design alternatives (i.e., super tall building in Seoul, Korea). The project architect conducted the design work for the schematic design as well as for the two schematic design alternatives. The schematic design has 110 stories and is $540 \mathrm{~m}$ high. One schematic design alternative has 105 stories and is $519 \mathrm{~m}$ high, while the other has 115 stories and is $561 \mathrm{~m}$ high. The quantity surveyors collected their respective design data (i.e., height, stories, floor area, core area, gross floor area, gross core area, etc.) and estimated their respective cost data (i.e., floor quantity, floor material cost, floor equipment cost, floor labor cost, etc.). Finally, the respective construction costs and unit costs of the three pilot design alternatives were determined.

The unit cost of $115 \mathrm{~F}-561 \mathrm{~m}$ increased more than the unit cost of $110 \mathrm{~F}-540 \mathrm{~m}$, while the unit cost of $105 \mathrm{~F}-519 \mathrm{~m}$ decreased more than the unit cost of $110 \mathrm{~F}-540 \mathrm{~m}$. The unit cost variation ratio between $110 \mathrm{~F}-540 \mathrm{~m}$ and $115 \mathrm{~F}-561 \mathrm{~m}$ was greater than that between $105 \mathrm{~F}-519 \mathrm{~m}$ and $110 \mathrm{~F}-540 \mathrm{~m}$. In other words, the higher the building, the more the unit cost rate increased. Conversely, the lower the building, the less the unit cost rate decreased. To identify the relationship between building height and the unit cost rate, this study proposes the high-rise premium ratio, which is a productivity ratio.

To construct this ratio, the main factors that impact the construction cost of super tall and low-rise buildings were considered (see Fig. 1).

The structural system is the important criterion for the development of super tall buildings as it unites plan shape, floor plate, lease span, floor height, building form, service core, and vertical transportation (Ho 2007). For example, super tall building materials include SM 570 TMCP steel 
Table 1. Examples of super tall buildings.

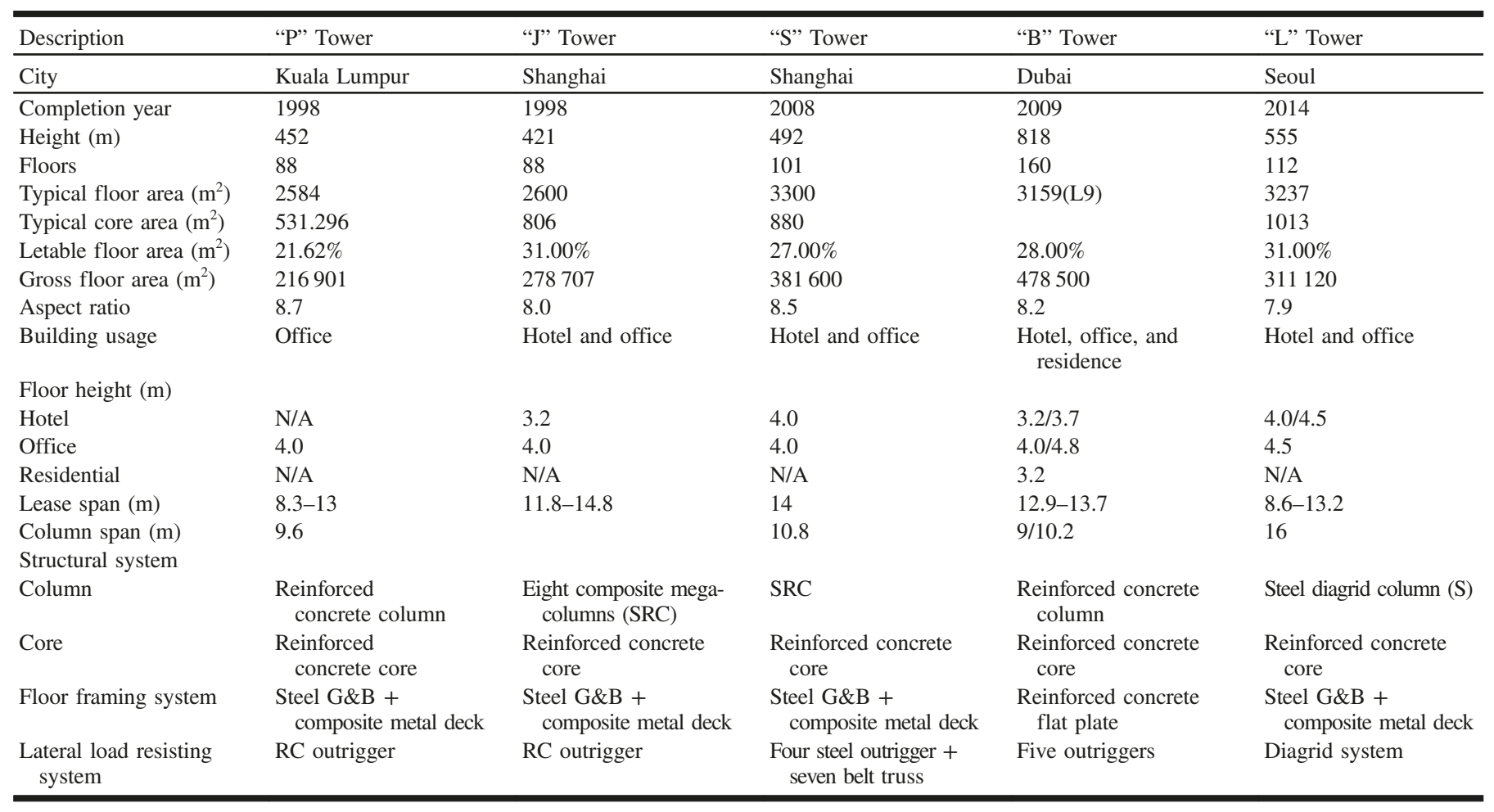

Fig. 1. Comparison of cost factors between high-rise and low-rise buildings.

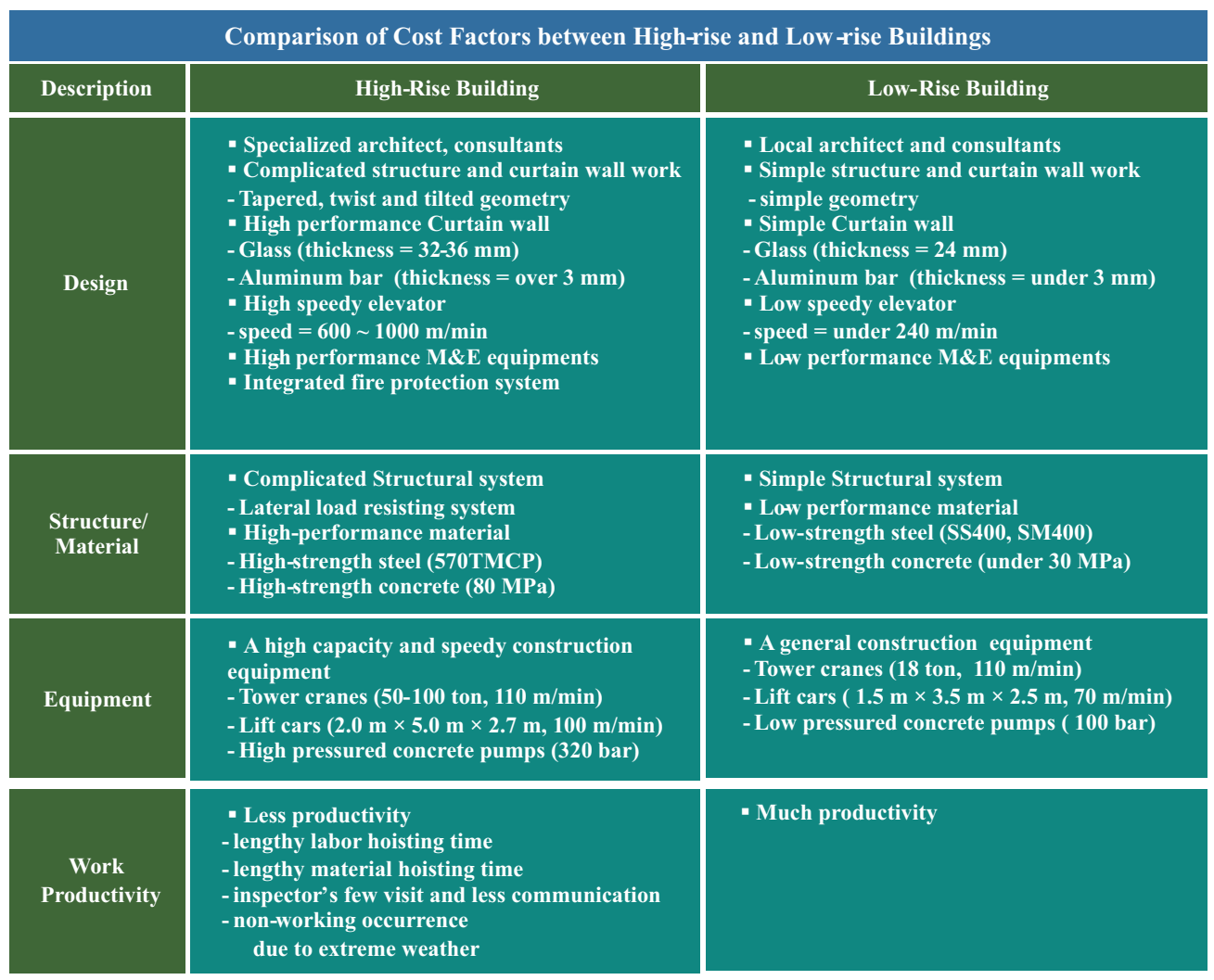

and $80 \mathrm{MPa}$ concrete, while SM 400 steel and $30 \mathrm{MPa}$ concrete are commonly used materials in low-rise buildings. Equipment used for super tall buildings include 100 ton tower cranes and 320 bar concrete pumps, while, on average, 18 ton tower cranes and 100 bar concrete pumps are utilized in low-rise building work. 
Fig. 2. High-rise premium ratio framework (RTT, return trip time). Abbreviations used are defined as follows: Labor RTT1 ${ }_{n}(\mathrm{~s})$ is labor's morning and evening return trip time traveling between first floor and $n$ floor by hoist. Labor RTT $2_{n}$ (s) is the summation of labor's morning and evening return trip time and hoist platform dwelling time between first floor and $n$ floor. Lunch RTT $n$ (s) is labor's lunch return trip time traveling between $n$ floor and a high-rise canteen by hoist. Labor RTT3 $n$ (s) is the summation of labor's morning and evening return trip time and hoist platform dwelling time and labor's lunch return trip time between first floor and $n$ floor. Material RTT $1_{n}(\mathrm{~s})$ is material's return trip time traveling between first floor and $n$ floor by hoist. Material RTT $2_{n}(\mathrm{~s})$ is the summation of material's return trip time and hoist platform dwelling time between first floor and $n$ floor. Material RTT3 $n$ (s) is that Material RTT2 is occurred three times per day on the average between first floor and $n$ floor.

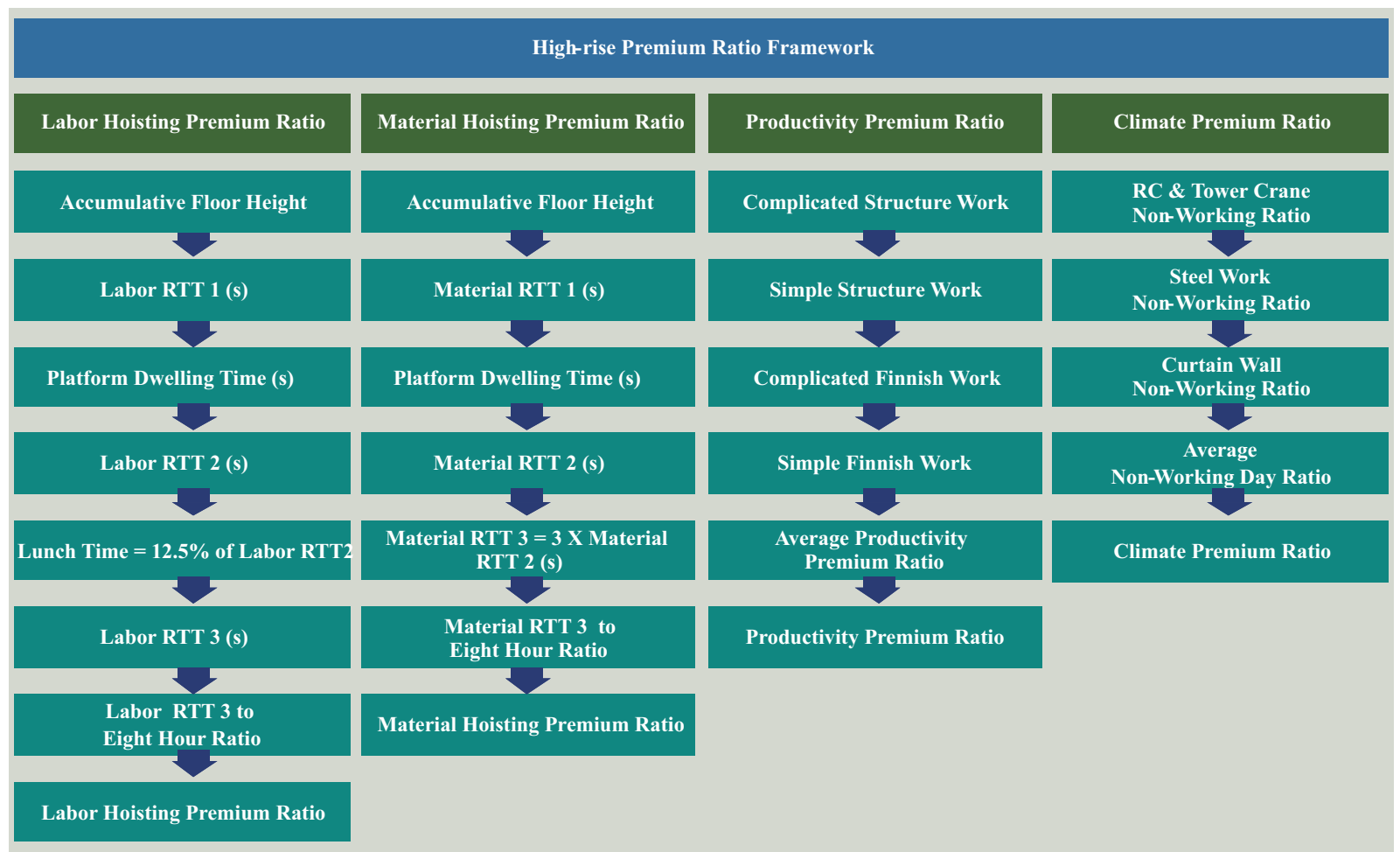

Fig. 3. Return trip time (RTT) for lunch.

\section{Lunch RTT $=12.5 \%$ of Labor RTT 2}

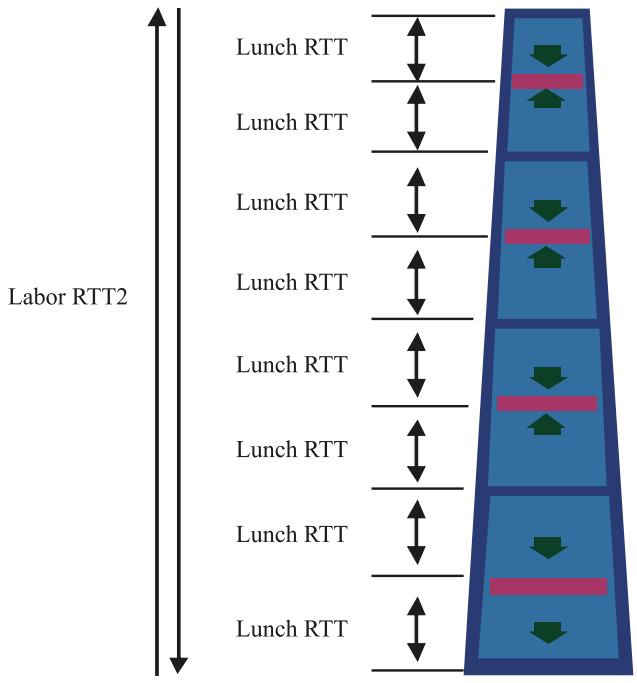

High-Rise Canteen 4

High-Rise Canteen 3

High-Rise Canteen 2

High-Rise Canteen 1

These material and equipment costs are directly reflected in construction cost, as it is difficult to find the variation ratio of material and equipment cost. Therefore, they are not considered in this research. However, labor cost can be esti- mated by the high-rise premium ratio, which changes according to the building height of a super tall building. This ratio is utilized to develop the proposed SCEM.

\section{High-rise premium ratio}

The high-rise premium ratio can be defined as a productivity ratio of super tall building construction that affects the variation of unit cost as the number of building stories changes (see Fig. 2). The high-rise premium ratio framework consists of: (1) a labor hoisting premium ratio (i.e., the time it takes labor to travel to and from the workshop by hoist); (2) a material hoisting premium ratio (i.e., the time it takes for materials to travel to and from the workshop by hoist); (3) a productivity premium ratio (i.e., productivity reduction at the high-rise building's exterior workshop, inefficiency caused by few inspector visits to the high-rise workshop, and ineffectiveness caused by minimal communication between the inspector and the high-rise workshop); and (4) a climate premium ratio (i.e., the non-working occurrences due to extreme weather during the workday).

\subsection{Labor hoisting premium ratio}

The labor hoisting premium ratio aims to calculate the work time lost as workers travel up and down by hoist. There are three types of labor trip times: (1) the time it takes for labor to make a single morning trip from the ground floor to 
Table 2. Productivity premium ratio by high-rise work.

\begin{tabular}{lllll}
\hline \multicolumn{5}{c}{ Productivity premium ratio } \\
\cline { 2 - 5 } & $\begin{array}{l}\text { Complicated } \\
\text { structure work } \\
(\%)\end{array}$ & $\begin{array}{l}\text { Simple struc- } \\
\text { ture work }(\%)\end{array}$ & $\begin{array}{l}\text { Complicated fin- } \\
\text { ish work }(\%)\end{array}$ & $\begin{array}{l}\text { Simple finish } \\
\text { work }(\%)\end{array}$ \\
\hline Height $(\mathrm{m})$ & 70 & 50 & 60 & 30 \\
$551-600$ & 64 & 46 & 55 & 27 \\
$451-500$ & 58 & 42 & 50 & 25 \\
$401-450$ & 52 & 37 & 45 & 22 \\
$351-400$ & 46 & 33 & 40 & 20 \\
$301-350$ & 40 & 29 & 35 & 17 \\
$251-300$ & 34 & 25 & 29 & 15 \\
$201-250$ & 28 & 20 & 24 & 12 \\
$151-200$ & 22 & 16 & 19 & 7 \\
$101-150$ & 16 & 12 & 14 & 5 \\
$51-100$ & 11 & 8 & 9 & 2 \\
$25-50$ & 5 & 3 & 4 & \\
\hline
\end{tabular}

Fig. 4. Schematic cost estimating model framework.

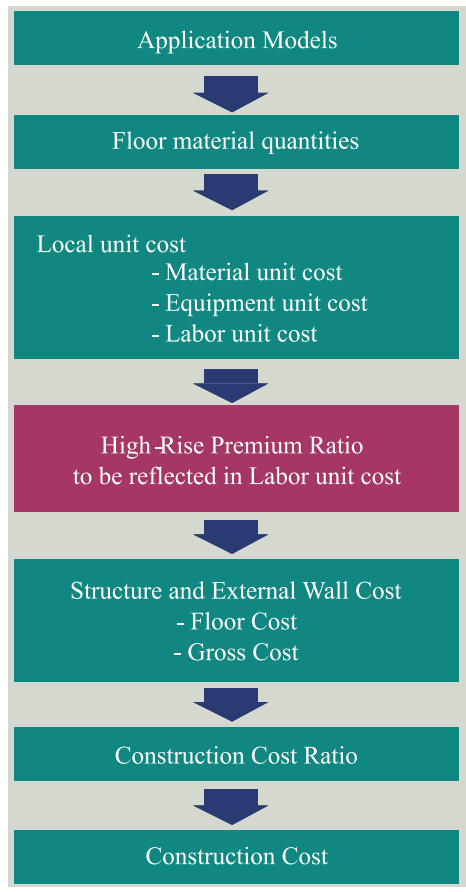

the workplace before work commences; (2) the time it takes for labor to go from the workplace to a high-rise canteen for lunch and return back to the workplace after lunch; and (3) the time it takes for labor to make a single evening trip from the workplace to the ground floor after the workday is over. The labor hoisting premium ratio is the ratio of the summed labor trip times to eight working hours per day. After analyzing the actual labor hoisting data from the "P" Tower and " $T$ " project, the following conditions were found: (1) a single trip between the ground floor and the 100th floor is generally $40 \mathrm{~min}$ by hoist, while a return trip from the 100th floor to the ground floor is $80 \mathrm{~min}$ (return trip time: RTT) on average; (2) platforms are located at every floor, and the hoist generally stops at a platform every sixth floor, the platform dwelling time is $60 \mathrm{~s}$, while the ground platform dwelling time is $300 \mathrm{~s}$; (3) there are four high-rise canteens
Fig. 5. Case project profile.

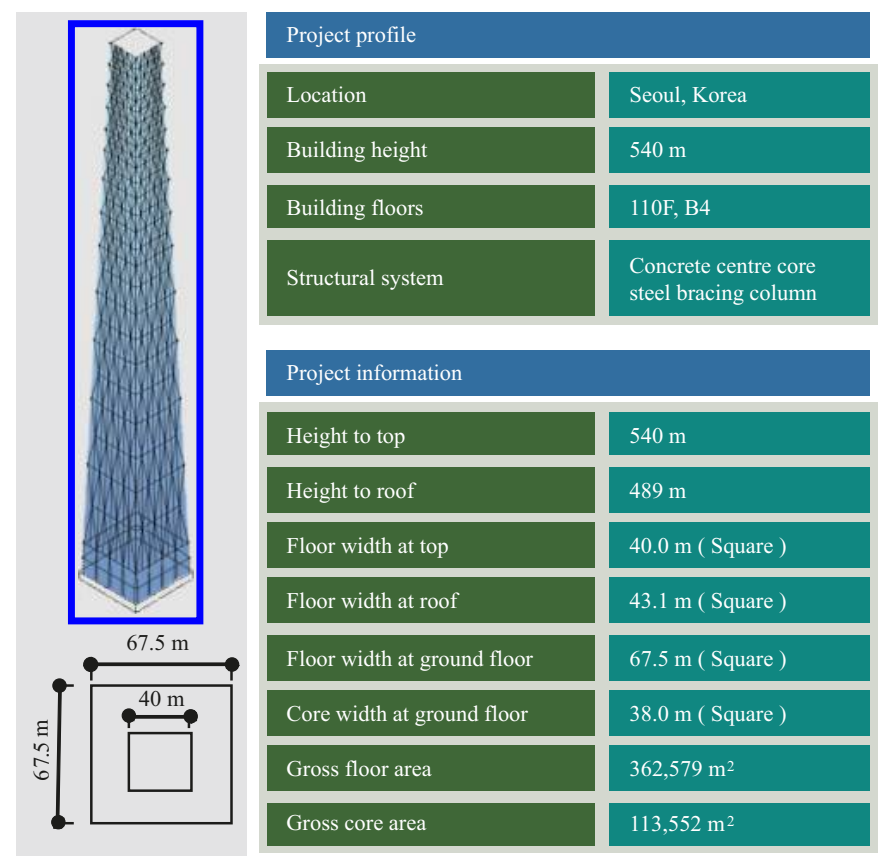

located at every 30th floor (i.e., 30th floor, 60th floor, 90th floor, 110th floor). In the labor workshop area, the four high-rise canteens accommodate eight zones of workplace (see Fig. 3); therefore, labor RTT for lunch is $12.5 \%$ of the labor RTT to the workshop (see eq. [4]).

The equations of the labor hoisting premium ratio are defined as follows:

For labor $\mathrm{RTT}_{n}$

$$
\mathrm{L} \_\mathrm{RTT}_{1}=\frac{2 \times \sum_{i=1}^{n} \mathrm{FH}_{i}}{\mathrm{HS}}
$$

where $\mathrm{L}_{-} \mathrm{RTT}_{n}$ is labor $\mathrm{RTT}_{n}(\mathrm{~s}) ; \mathrm{FH}_{i}$ is floor height (m) of $n$ floor; HS is hoist speed $(\mathrm{m} / \mathrm{s}) ; i$ is a variable denoted by the number of floors; $n$ is the number of floors. 
Fig. 6. Case Model_ Nine Models.

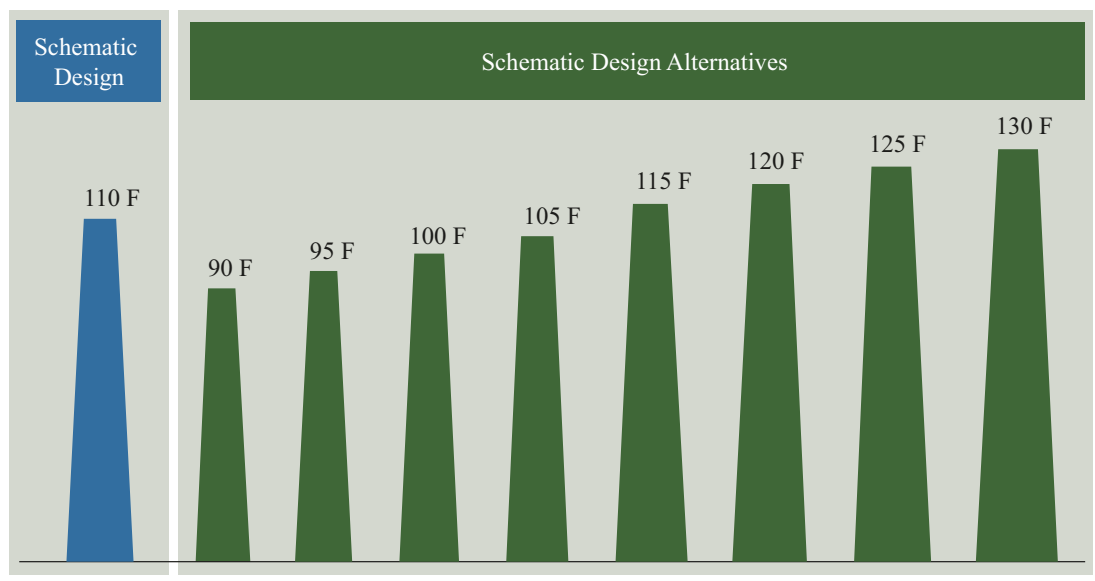

Table 3. Case model codes.

\begin{tabular}{lllll}
\hline Description & Code & Stories & $\begin{array}{l}\text { Height to top } \\
(\mathrm{m})\end{array}$ & $\begin{array}{l}\text { Height to roof } \\
(\mathrm{m})\end{array}$ \\
\hline Schematic design & S110-540 & 110 & 540 & 489 \\
SD Alternative A & A90-454 & 90 & 454 & 403 \\
SD Alternative B & A95-477 & 95 & 477 & 426 \\
SD Alternative C & A100-498 & 100 & 498 & 447 \\
SD Alternative D & A105-519 & 105 & 519 & 468 \\
SD Alternative E & A115-561 & 115 & 561 & 510 \\
SD Alternative F & A120-583 & 120 & 583 & 532 \\
SD Alternative G & A125-604 & 125 & 604 & 553 \\
SD Alternative H & A130-625 & 130 & 625 & 574 \\
\hline
\end{tabular}

Note: S, schematic design; A, schematic design alternative.

For labor RTT2 ${ }_{n}$

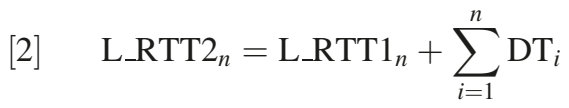

where L_RTT2 ${ }_{n}$ is labor $\mathrm{RTT}_{2}(\mathrm{~s}) ; \mathrm{L}_{-} \mathrm{RTT}_{n}$ is labor $\mathrm{RTT}_{n}$ (s); $\mathrm{DT}_{i}$ is hoist platform dwelling time (s) between first floor and $n$ floor; $i$ is a variable denoted by the number of floors; $n$ is the number of floors.

For lunch $\mathrm{RTT}_{n}$

$$
\text { [3] } \mathrm{LU}_{\mathrm{RTT}}{ }_{n}=\frac{\mathrm{L} \_\mathrm{RTT}_{n}}{\mathrm{WZ}}
$$

where LU_RTT ${ }_{n}$ is lunch $\mathrm{RTT}_{n}(\mathrm{~s})$; $\mathrm{L}_{-} \mathrm{RTT}_{i}$ is labor $\mathrm{RTT}_{n}$ (s); $i$ is a variable denoted by the number of floors; $n$ is the number of floors; WZ is a number of workplace zones divided by high-rise canteens and is 8 workplace zones by 4 high-rise canteens in this case.

For labor RTT3

$$
\text { [4] L_RTT3 }{ }_{n}=\mathrm{L} \_R T T 22_{n}+\mathrm{LU}_{-} \mathrm{RTT}_{n}
$$

where L_RTT3 ${ }_{n}$ is labor RTT3 ${ }_{n}(\mathrm{~s}) ; \mathrm{L}_{-} \mathrm{RTT} 2_{n}$ is labor RTT2 ${ }_{n}$ (s); LU_RTT ${ }_{n}$ is lunch $\mathrm{RTT}_{n}(\mathrm{~s})$; $i$ is a variable denoted by the number of floors; $n$ is the number of floors.

For the labor hoisting premium ratio

[5] $\quad \mathrm{LHPR}_{n}=\frac{\mathrm{L} \_\mathrm{RTT}_{n}}{\mathrm{WH}}$ where $\mathrm{LHPR}_{n}$ is labor hoisting premium ratio (\%) at $n$ floor; $\mathrm{L}_{-} \mathrm{RTT}_{n}$ is labor $\mathrm{RTT}_{n}(\mathrm{~s}) ; i$ is a variable denoted by the number of floors; $n$ is the number of floors; WH is working hours per day and generally working hours per day is $8 \times$ 3600 (s) in this case.

\subsection{Material hoisting premium ratio}

At the case project worksite, during a common job, materials and tools were generally delivered three times a day. The material hoisting premium ratio can be defined as the ratio of the three return trip times (RTT) for material and tool delivery to eight working hours per day. The material hoisting premium ratio can be estimated under the following conditions: (1) platforms are located at every floor although the hoist stops at a platform every 12 floors on average; (2) the platform dwelling time is $300 \mathrm{~s}$; and (3) the ground platform dwelling time is $300 \mathrm{~s}$.

The equations of the material hoisting premium ratio are defined as follows:

For material $\mathrm{RTT}_{n}$

$$
\mathrm{M} R T T 1_{n}=\frac{2 \times \sum_{i=1}^{n} \mathrm{FH}_{i}}{\mathrm{HS}}
$$

where $\mathrm{M}_{-} \mathrm{RTT}_{n}$ is material $\mathrm{RTT}_{n}(\mathrm{~s}) ; \mathrm{FH}_{i}$ is floor height (m) of $n$ floor; HS is hoist speed $(\mathrm{m} / \mathrm{s}) ; i$ is a variable denoted by the number of floors; $n$ is the number of floors. 


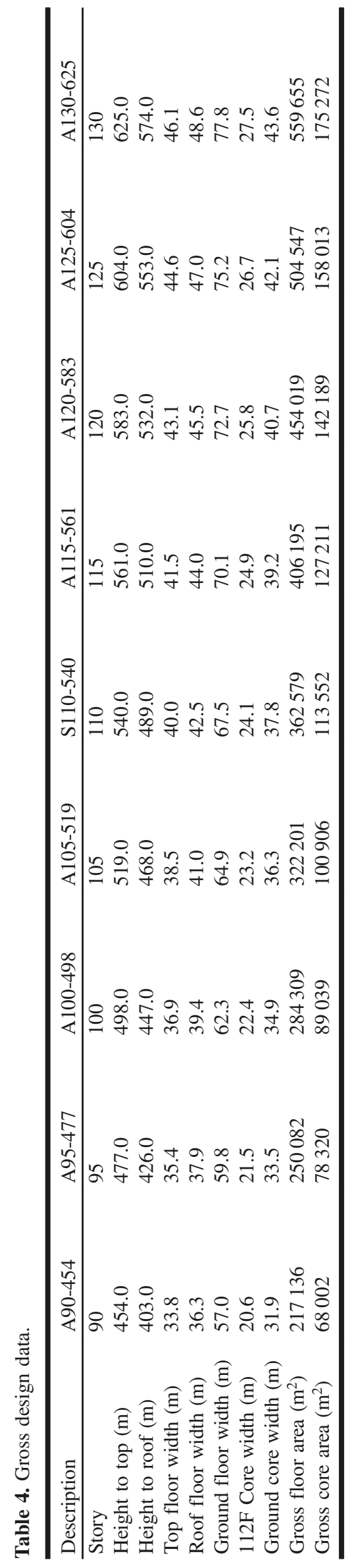

For material RTT2 ${ }_{n}$

[7] $\mathrm{M}_{-} \mathrm{RTT} 2_{n}=\mathrm{M}_{-} \mathrm{RTT} 1_{n}+\sum_{i=1}^{n} \mathrm{PDT}_{i}$

where $\mathrm{M} \_\mathrm{RTT} 22_{n}$ is material $\mathrm{RTT} 2_{n}(\mathrm{~s}) ; \mathrm{M} \_\mathrm{RTT} 1_{n}$ is material $\mathrm{RTT1}_{n}(\mathrm{~s}) ; \mathrm{PDT}_{i}$ is hoist platform dwelling time (s) between first floor and $n$ floor; $i$ is a variable denoted by the number of floors; $n$ is the number of floors.

For material $\mathrm{RTT}_{n}$

[8] $\mathrm{M}_{-} \mathrm{RTT} 3_{n}=\mathrm{DT} \times \mathrm{M}_{-} \mathrm{RTT} 2_{n}$

where $\mathrm{M} \_\mathrm{RTT} 3_{n}$ is material $\mathrm{RTT} 3_{n}(\mathrm{~s}) ; \mathrm{M} \_\mathrm{RTT} 2_{n}$ is material $\mathrm{RTT}_{n}(\mathrm{~s}) ; i$ is a variable denoted by the number of floors; $n$ is the number of floors; DT is a number of delivery times per day and generally three deliveries of materials and tools per day is applied in this case.

For the material hoisting premium ratio

$$
\mathrm{MHPR}_{n}=\frac{\mathrm{M}_{-} \mathrm{RTT} 3_{n}}{\mathrm{WH}}
$$

where MHPR is material hoisting premium ratio (\%) at $n$ floor; $\mathrm{M} \_\mathrm{RTT} 3_{n}$ is material $\mathrm{RTT}_{n}(\mathrm{~s}) ; i$ is a variable denoted by the number of floors; $n$ is the number of floors; WH is working hours per day and generally working hours per day is $8 \times 3600$ (s) in this case.

\subsection{Productivity premium ratio}

The productivity premium ratio can be defined as productivity reduction due to inefficiency in super tall building construction. Productivity reduction results from: (1) productivity reduction at the exterior workshop of the high-rise building project; (2) inefficiency due to few inspector visits to the high-rise workshop; and (3) ineffectiveness due to minimal communication between the inspector and the high-rise workshop. Collecting these ratio data from existing super tall buildings is extraordinarily difficult as access is very limited. This research develops this productivity premium ratio based on "P" Tower in Kuala Lumpur of Malaysia only. The productivity premium ratio is indicated for a complicated structure work, a simple structure work, a complicated finish work, a simple finish work in response to increases and decreases in building height (see Table 2).

However, the productivity premium ratio often varied according to work environment, structure type, and finish work grade. Thus, this ratio should be utilized flexibly after considering various building conditions.

\subsection{Climate premium ratio}

The climate premium ratio is used to determine the rate of lost work time due to severe weather during the workday. Climate data pertaining to severe weather causing non-working days were collected in terms of temperature, snow, rain, and wind at $50 \mathrm{~m}, 100 \mathrm{~m}, 200 \mathrm{~m}, 300 \mathrm{~m}, 400 \mathrm{~m}, 500 \mathrm{~m}$, and $600 \mathrm{~m}$ for the years 2004 to 2008 from the Korea Meteorological Administration (KMA). According to this data, non-working days were found to be caused by the following conditions: (1) for concrete work and tower crane work, nonworking days result when the temperature is below minus $10{ }^{\circ} \mathrm{C}$, when there is over $10 \mathrm{~mm}$ of snow, over $10 \mathrm{~mm}$ of 
Table 5. Labor hoisting premium ratio.

\begin{tabular}{|c|c|c|c|c|c|c|c|c|}
\hline Floor & $\begin{array}{l}\text { Floor height } \\
\text { (m) }\end{array}$ & $\begin{array}{l}\text { Accumulative } \\
\text { floor height } \\
(\mathrm{m})\end{array}$ & $\begin{array}{l}\text { Labor RTT1 } \\
\text { (s) }\end{array}$ & \multicolumn{5}{|c|}{ Labor hoisting premium ratio } \\
\hline 135 & 1.415 & 590.3 & 1416.6 & & 3037 & 3416 & 11.9 & 10.7 \\
\hline 132 & 3.710 & 578.3 & 1387.9 & 60 & 3008 & 3384 & 11.7 & 10.6 \\
\hline 131 & 4.600 & 573.7 & 1376.9 & & 2937 & 3304 & 11.5 & 10.3 \\
\hline 130 & 3.505 & 570.2 & 1368.4 & & 2928 & 3294 & 11.4 & 10.3 \\
\hline 129 & 3.870 & 566.3 & 1359.2 & & 2919 & 3284 & 11.4 & 10.2 \\
\hline 128 & 4.625 & 561.7 & 1348.1 & & 2908 & 3272 & 11.4 & 10.2 \\
\hline 127 & 4.000 & 557.7 & 1338.5 & & 2898 & 3261 & 11.3 & 10.2 \\
\hline 122 & 4.000 & 537.7 & 1290.5 & & 2790 & 3139 & 10.9 & 9.7 \\
\hline 121 & 4.000 & 533.7 & 1280.9 & & 2781 & 3128 & 10.9 & 9.7 \\
\hline 120 & 4.000 & 529.7 & 1271.3 & 60 & 2771 & 3118 & 10.8 & 9.7 \\
\hline
\end{tabular}

Table 6. Material hoisting premium ratio.

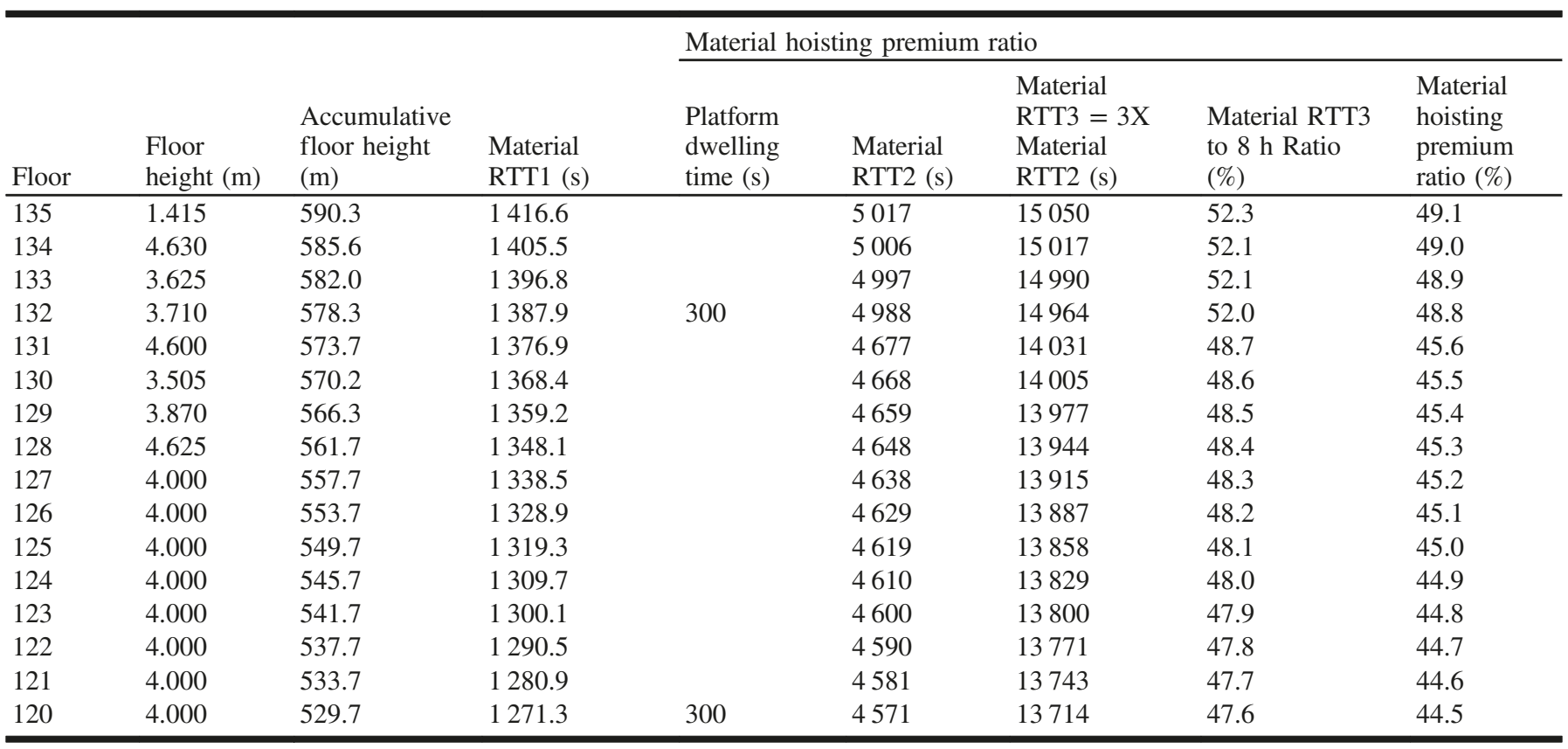

rain, and wind over $10 \mathrm{~m} / \mathrm{s}$; (2) for steel work, non-working days result when the temperature is below minus $10{ }^{\circ} \mathrm{C}$, when there is over $5 \mathrm{~mm}$ of snow, over $5 \mathrm{~mm}$ of rain, and wind over $10 \mathrm{~m} / \mathrm{s}$; and (3) for curtain wall work, non-working days result when the temperature is below minus $4{ }^{\circ} \mathrm{C}$, when there is over $5 \mathrm{~mm}$ of snow, over $5 \mathrm{~mm}$ of rain, and wind gusts of over $10 \mathrm{~m} / \mathrm{s}$.

The non-working day ratio of concrete work and tower crane, steel work, and curtain wall work can be calculated by dividing non-working days by 365 days. The climate premium ratio is $25 \%$ (i.e., $25 \%=50 \% \times 50 \%$ ) of the average non-working day ratio, as the probability that severe weather will occur after labor arrives at the worksite is $50 \%$, while the probability that severe weather will occur during the workday is $50 \%$.

The climate premium ratio is defined as follows:

[10] $\quad \mathrm{CPR}_{n}=0.25 \times\left(\frac{\mathrm{RTNPR}_{n}+\mathrm{SNPR}_{n}+\mathrm{CNPR}_{n}}{3}\right)$

where $\mathrm{CPR}_{n}$ is climate premium ratio (\%) at $n$ floor; $\mathrm{RTNPR}_{n}$ is reinforced concrete work and tower crane work non-working day ratio (\%) at $n$ floor; $\mathrm{SNPR}_{n}$ is steel work non-working day ratio (\%) at $n$ floor; $\mathrm{CNPR}_{n}$ is curtain wall 
Table 7. Productivity premium ratio.

\begin{tabular}{|c|c|c|c|c|c|}
\hline \multirow[b]{2}{*}{ Floor } & \multirow[b]{2}{*}{$\begin{array}{l}\text { Floor } \\
\text { height (m) }\end{array}$} & \multirow[b]{2}{*}{$\begin{array}{l}\text { Accumulative floor } \\
\text { height }(\mathrm{m})\end{array}$} & \multicolumn{3}{|c|}{ Productivity premium ratio } \\
\hline & & & $\begin{array}{l}\text { Complicated } \\
\text { structure work (\%) }\end{array}$ & $\begin{array}{l}\text { Simple } \\
\text { finish } \\
\text { work }(\%)\end{array}$ & $\begin{array}{l}\text { Productivity pre- } \\
\text { mium ratio }(\%)\end{array}$ \\
\hline 135 & 1.415 & 590.3 & 70 & 30.0 & 100.0 \\
\hline 134 & 4.630 & 585.6 & 70 & 30.0 & 100.0 \\
\hline 133 & 3.625 & 582.0 & 70 & 30.0 & 100.0 \\
\hline 132 & 3.710 & 578.3 & 70 & 30.0 & 100.0 \\
\hline 131 & 4.600 & 573.7 & 70 & 30.0 & 100.0 \\
\hline 130 & 3.505 & 570.2 & 70 & 30.0 & 100.0 \\
\hline 129 & 3.870 & 566.3 & 70 & 30.0 & 100.0 \\
\hline 128 & 4.625 & 561.7 & 70 & 30.0 & 100.0 \\
\hline 127 & 4.000 & 557.7 & 70 & 30.0 & 100.0 \\
\hline 126 & 4.000 & 553.7 & 70 & 30.0 & 100.0 \\
\hline 125 & 4.000 & 549.7 & 64 & 27.0 & 91.0 \\
\hline 124 & 4.000 & 545.7 & 64 & 27.0 & 91.0 \\
\hline 123 & 4.000 & 541.7 & 64 & 27.0 & 91.0 \\
\hline 122 & 4.000 & 537.7 & 64 & 27.0 & 91.0 \\
\hline 121 & 4.000 & 533.7 & 64 & 27.0 & 91.0 \\
\hline 120 & 4.000 & 529.7 & 64 & 27.0 & 91.0 \\
\hline
\end{tabular}

non-working day ratio (\%) at $n$ floor; $i$ is a variable denoted by the number of floors; $n$ is the number of floors.

\subsection{High-rise premium ratio}

The high-rise premium ratio is the sum of the labor hoisting premium ratio, material hoisting premium ratio, productivity premium ratio, and climate premium ratio.

The high-rise premium ratio is defined as follows:

$$
\text { [11] } \quad \mathrm{HRPR}_{n}=\mathrm{LHPR}_{n}+\mathrm{MHPR}_{n}+\mathrm{MPR}_{n}+\mathrm{CPR}_{n}
$$

where $\mathrm{HRPR}_{n}$ is high-rise premium ratio (\%) at $n$ floor; $\mathrm{LHPR}_{n}$ is labor hoisting premium ratio (\%) at $n$ floor; $\mathrm{MHPR}_{n}$ is material hoisting premium ratio (\%) at $n$ floor; $\mathrm{MPR}_{n}$ is productivity premium ratio (\%) at $n$ floor; $\mathrm{CPR}_{n}$ is climate premium ratio (\%) at $n$ floor; $i$ is a variable denoted by the number of floors; $n$ is the number of floors.

This ratio affects the labor cost of super tall building construction in response to increases and decreases in building height.

\section{Schematic cost estimating model (SCEM)}

As super tall buildings are generally large in scale, complex in nature, and involve high construction costs, the economic planning of super tall building construction is particularly important (Ho 2007). Thus, accurate preliminary estimating is crucial, as its primary function is to forecast the probable cost of a future project before the building has been designed in detail and contract particulars are prepared (Seeley 1996). However, owners are generally required to use cost estimates that originate from initial ideas and that are without accompanying physical documents. Figure 4 shows the proposed schematic cost estimating model (SCEM) framework, which consists of material quantity, local unit cost (i.e., material, equipment, and labor), high-rise premium applied to labor unit cost, structure and external wall cost, and construction cost.

To facilitate schematic design and determine design alternatives for super tall buildings, the application model incorpo- rates nine models to reflect changes in building stories. The schematic design (SD) can be defined as $n$ floors, while the SD alternatives are $n-20$ floors, $n-15$ floors, $n-10$ floors, $n-5$ floors, $n+5$ floors, $n+10$ floors, $n+15$ floors, and $n+20$ floors, by changing the number of building stories every five stories (i.e., $\pm 5, \pm 10, \pm 15, \pm 20$ stories).

Architect yields floor and gross design data for the nine application models. The floor design data is divided into the following components: story, floor height, floor width, floor area, and core area. Subsequently, the floor design data can be summarized as gross design data, which consists of gross stories, gross height, ground floor width, gross floor area, and gross core area.

Based on these application models, quantity surveyor estimates floor material quantities for 15 major elements in structure and external wall construction. These quantity elements include core wall concrete, core wall form, core wall rebar, core slab concrete, core slab form, core slab rebar, mega column concrete, mega column form, mega column rebar, perimeter slab concrete, perimeter slab form, perimeter slab rebar, steel floor framing, outrigger and belt truss, and curtain wall.

The floor cost is calculated by the aforementioned $15 \mathrm{ma}-$ terial quantities multiplied by local price. This local cost is obtained by considering project location, inflation, environmental aspects, regulatory requirements, among others.

The high-rise premium ratio is utilized to estimate the labor unit cost among local unit cost (i.e., material, equipment, and labor). Equation [12] indicates the equation to estimate a super tall building's floor cost by multiplying floor material quantity by the sum of material unit cost, equipment unit cost, labor unit cost reflected by the high-rise premium ratio.

The equation for floor cost is as follows:

$$
\text { [12] } \begin{aligned}
\mathrm{FC}_{n} & =\mathrm{FMQ}_{n} \\
& \times\left(\mathrm{MUC}_{n}+\mathrm{EUC}_{n}+\mathrm{LUC}_{n}+\mathrm{LUC}_{n} \times \mathrm{HRPR}_{n}\right)
\end{aligned}
$$

where $\mathrm{FC}_{\mathrm{n}}$ is floor cost at $n$ floor; $\mathrm{FMQ}_{n}$ is floor material 
Table 8. Non-working day ratio.

\begin{tabular}{|c|c|c|c|c|c|c|}
\hline Activity & \multicolumn{6}{|c|}{ Summary of concrete, tower crane, steel, and curtain wall work } \\
\hline Year & \multicolumn{6}{|c|}{ Year 2004-2008 Average non-working days } \\
\hline Height $(\mathrm{m})$ & Temperature & Snow & Rain & Wind & Total & Ratio $(\%)$ \\
\hline $501-600$ & 31.8 & 0.8 & 36.7 & 57.2 & 126.5 & 34.6 \\
\hline $401-500$ & 26.9 & 0.8 & 36.7 & 44.7 & 109.0 & 29.9 \\
\hline $301-400$ & 22.9 & 0.8 & 36.7 & 34.3 & 94.7 & 25.9 \\
\hline 201-300 & 19.5 & 0.8 & 36.7 & 20.9 & 77.9 & 21.3 \\
\hline $101-200$ & 17.6 & 0.9 & 36.7 & 8.3 & 63.4 & 17.4 \\
\hline $50-100$ & 15.3 & 0.9 & 36.7 & 1.9 & 54.7 & 15.0 \\
\hline Activity & \multicolumn{6}{|c|}{ Concrete and tower crane work } \\
\hline Year & \multicolumn{6}{|c|}{ Year 2004-2008 Average non-working days for 5 years } \\
\hline Height (m) & Temperature & Snow & Rain & Wind & Total & Ratio $(\%)$ \\
\hline $501-600$ & 19.4 & 0.2 & 29.2 & 63.6 & 112.4 & 30.8 \\
\hline $401-500$ & 14.6 & 0.2 & 29.2 & 51.0 & 95 & 26.0 \\
\hline $301-400$ & 11.6 & 0.2 & 29.2 & 39.0 & 80 & 21.9 \\
\hline $201-300$ & 8.8 & 0.2 & 29.2 & 24.0 & 62.2 & 17.0 \\
\hline $101-200$ & 7.2 & 0.2 & 29.2 & 9.4 & 46 & 12.6 \\
\hline $50-100$ & 5.2 & 0.2 & 29.2 & 2.4 & 37 & 10.1 \\
\hline Activity & \multicolumn{6}{|l|}{ Steel work } \\
\hline Year & \multicolumn{6}{|c|}{ Year 2004-2008 Average non-working days } \\
\hline Height $(\mathrm{m})$ & Temperature & Snow & Rain & Wind & Total & Ratio (\%) \\
\hline $501-600$ & 19.4 & 1.4 & 40.4 & 60.2 & 121.4 & 33.3 \\
\hline $401-500$ & 14.6 & 1.4 & 40.4 & 45.6 & 102 & 27.9 \\
\hline $301-400$ & 11.6 & 1.4 & 40.4 & 34.4 & 87.8 & 24.1 \\
\hline $201-300$ & 8.8 & 1.4 & 40.4 & 21.0 & 71.6 & 19.6 \\
\hline $101-200$ & 7.2 & 1.4 & 40.4 & 8.2 & 57.2 & 15.7 \\
\hline $50-100$ & 5.2 & 1.4 & 40.4 & 1.8 & 48.8 & 13.4 \\
\hline Activity & \multicolumn{6}{|c|}{ Curtain wall work } \\
\hline Year & \multicolumn{6}{|c|}{ Year 2004-2008 Average non-working days } \\
\hline Height $(\mathrm{m})$ & Temperature & Snow & Rain & Wind & Total & Ratio (\%) \\
\hline $501-600$ & 56.6 & 0.8 & 40.4 & 47.8 & 145.6 & 39.9 \\
\hline $401-500$ & 51.4 & 0.8 & 40.4 & 37.4 & 130 & 35.6 \\
\hline $301-400$ & 45.4 & 0.8 & 40.4 & 29.6 & 116.2 & 31.8 \\
\hline $201-300$ & 41 & 0.8 & 40.4 & 17.6 & 99.8 & 27.3 \\
\hline $101-200$ & 38.4 & 1 & 40.4 & 7.2 & 87 & 23.8 \\
\hline $50-100$ & 35.6 & 1 & 40.4 & 1.4 & 78.4 & 21.5 \\
\hline
\end{tabular}

quantity at $n$ floor; $\mathrm{MUC}_{n}$ is material unit cost at $n$ floor; $\mathrm{EUC}_{n}$ is equipment unit cost at $n$ floor; $\mathrm{LUC}_{n}$ is labor unit cost at $\mathrm{n}$ floor; $\mathrm{HRPR}_{n}$ is high-rise premium ratio at $n$ floor; $i$ is a variable denoted by the number of floors; $n$ is the number of floors.

Based on this floor cost, gross amount (the structure and external wall cost) can be computed.

The equation for gross amount is as follows:

[13] $\mathrm{GA}=\sum_{i=1}^{n} \mathrm{FC}_{i}$

where GA is gross amount; FC is floor cost; $i$ is a variable denoted by the number of floors; $n$ is the total number of floors.

Furthermore, the construction cost can be estimated by applying the factor method (Bakewell et al. 1999). The factor method is commonly used for cost estimation in a construc- tion project where the cost of specialized items makes up a major portion of the total project cost. These ratios confirmed that the structure and external wall costs make up the highest proportion. Thus the ratios can be used to estimate the construction costs by applying the factor method.

\section{Case study}

To validate the theoretical framework of the SCEM, an existing super tall building was selected as a case project. Figure 5 describes the project profile of an actual tapered super tall building project that is currently ongoing in Korea.

This super tall building tapers from an area of $67.5 \mathrm{~m}^{2}$ at the bottom, to an area of $40 \mathrm{~m}^{2}$ at the top. It has 110 stories and is $540 \mathrm{~m}$ high above the ground.

\subsection{Case model}

The case model is actually nine models (i.e., 90F, 95F, $100 \mathrm{~F}, 105 \mathrm{~F}, 110 \mathrm{~F}, 115 \mathrm{~F}, 120 \mathrm{~F}, 125 \mathrm{~F}$, and $130 \mathrm{~F}$ ) that are gen- 
Table 9. Climate premium ratio.

\begin{tabular}{|c|c|c|c|c|c|c|c|c|}
\hline Floor & $\begin{array}{l}\text { Floor } \\
\text { height } \\
(\mathrm{m})\end{array}$ & $\begin{array}{l}\text { Accumulative } \\
\text { floor height } \\
\text { (m) }\end{array}$ & \multicolumn{6}{|c|}{ Climate premium ratio (non-working ratio) } \\
\hline 135 & 1.415 & 590.3 & 34.2 & 36.4 & 44.2 & 38.2 & 23.3 & 5.8 \\
\hline 134 & 4.630 & 585.6 & 34.2 & 36.4 & 44.2 & 38.2 & 23.3 & 5.8 \\
\hline 133 & 3.625 & 582.0 & 34.2 & 36.4 & 44.2 & 38.2 & 23.3 & 5.8 \\
\hline 130 & 3.505 & 570.2 & 34.2 & 36.4 & 44.2 & 38.2 & 23.3 & 5.8 \\
\hline 129 & 3.870 & 566.3 & 34.2 & 36.4 & 44.2 & 38.2 & 23.3 & 5.8 \\
\hline 128 & 4.625 & 561.7 & 34.2 & 36.4 & 44.2 & 38.2 & 23.3 & 5.8 \\
\hline 127 & 4.000 & 557.7 & 34.2 & 36.4 & 44.2 & 38.2 & 23.3 & 5.8 \\
\hline 126 & 4.000 & 553.7 & 34.2 & 36.4 & 44.2 & 38.2 & 23.3 & 5.8 \\
\hline 125 & 4.000 & 549.7 & 34.2 & 36.4 & 44.2 & 38.2 & 23.3 & 5.8 \\
\hline 121 & 4.000 & 533.7 & 34.2 & 36.4 & 44.2 & 38.2 & 23.3 & 5.8 \\
\hline 120 & 4.000 & 529.7 & 34.2 & 36.4 & 44.2 & 38.2 & 23.3 & 5.8 \\
\hline
\end{tabular}

Table 10. High-rise premium ratio.

\begin{tabular}{|c|c|c|c|c|c|c|c|}
\hline Floor & $\begin{array}{l}\text { Floor } \\
\text { height (m) }\end{array}$ & $\begin{array}{l}\text { Accumulative floor } \\
\text { height }(\mathrm{m})\end{array}$ & $\begin{array}{l}\text { Labor } \\
\text { hoisting } \\
\text { premium } \\
\text { ratio (\%) }\end{array}$ & $\begin{array}{l}\text { Material } \\
\text { hoisting } \\
\text { premium } \\
\text { ratio (\%) }\end{array}$ & $\begin{array}{l}\text { Productivity } \\
\text { premium ratio } \\
(\%)\end{array}$ & $\begin{array}{l}\text { Climate } \\
\text { premium } \\
\text { ratio }(\%)\end{array}$ & $\begin{array}{l}\text { High-rise } \\
\text { premium ratio } \\
(\%)\end{array}$ \\
\hline 135 & 1.415 & 590.3 & 10.7 & 49.1 & 100.0 & 5.8 & 165.6 \\
\hline 134 & 4.630 & 585.6 & 10.6 & 49.0 & 100.0 & 5.8 & 165.5 \\
\hline 133 & 3.625 & 582.0 & 10.6 & 48.9 & 100.0 & 5.8 & 165.4 \\
\hline 132 & 3.710 & 578.3 & 10.6 & 48.8 & 100.0 & 5.8 & 165.2 \\
\hline 131 & 4.600 & 573.7 & 10.3 & 45.6 & 100.0 & 5.8 & 161.7 \\
\hline 130 & 3.505 & 570.2 & 10.3 & 45.5 & 100.0 & 5.8 & 161.6 \\
\hline 129 & 3.870 & 566.3 & 10.2 & 45.4 & 100.0 & 5.8 & 161.5 \\
\hline 128 & 4.625 & 561.7 & 10.2 & 45.3 & 100.0 & 5.8 & 161.3 \\
\hline 127 & 4.000 & 557.7 & 10.2 & 45.2 & 100.0 & 5.8 & 161.2 \\
\hline 126 & 4.000 & 553.7 & 10.1 & 45.1 & 100.0 & 5.8 & 161.0 \\
\hline 125 & 4.000 & 549.7 & 9.8 & 45.0 & 91.0 & 5.8 & 151.6 \\
\hline 124 & 4.000 & 545.7 & 9.8 & 44.9 & 91.0 & 5.8 & 151.5 \\
\hline 123 & 4.000 & 541.7 & 9.8 & 44.8 & 91.0 & 5.8 & 151.4 \\
\hline 122 & 4.000 & 537.7 & 9.7 & 44.7 & 91.0 & 5.8 & 151.2 \\
\hline 121 & 4.000 & 533.7 & 9.7 & 44.6 & 91.0 & 5.8 & 151.1 \\
\hline 120 & 4.000 & 529.7 & 9.7 & 44.5 & 91.0 & 5.8 & 151.0 \\
\hline
\end{tabular}

erated by substituting $n$ for 110 in the generic nine models of the application model (i.e., $n-20 \mathrm{~F}, n-15 \mathrm{~F}, n-10 \mathrm{~F}$, $n-5 \mathrm{~F}, n \mathrm{~F}, n+5 \mathrm{~F}, n+10 \mathrm{~F}, n+15 \mathrm{~F}$, and $n+20 \mathrm{~F})$. This case model reflects changes in the number of building stories and is based on actual data (see Fig. 6). To verify the proposed theoretical framework, the case model is used for schematic estimation of the application model.

Table 3 shows that the case model is composed of S110-540, A90-454, A95-477, A100-498, A105-519, A115-561, A120583, A125-604, and A130-625. Within these codes, "S" indicates SD (one model) and "A" signifies SD alternatives (eight models). The second digit indicates building stories, while the third digit indicates building height. This case model's codes are utilized for design simulation and cost simulation.

\subsection{Design simulation data}

The schematic design (SD), as a base model, can be defined as S110-540. Subsequently, floor design data and gross design data can be collected from the SD.

Furthermore, an SD alternative can be determined by changing the number of building stories.

Then, by summarizing the floor design data, the gross design data of the nine case models can be displayed (see Table 4).

Among the design data of the nine case models (i.e., floor design data and gross design data), a comparison of gross floor area indicates that the nine models vary in stories: 90 stories (A90-454), 95 stories (A95-477), 100 stories (A100498), 105 stories (A105-519), 110 stories (S110-540), 115 


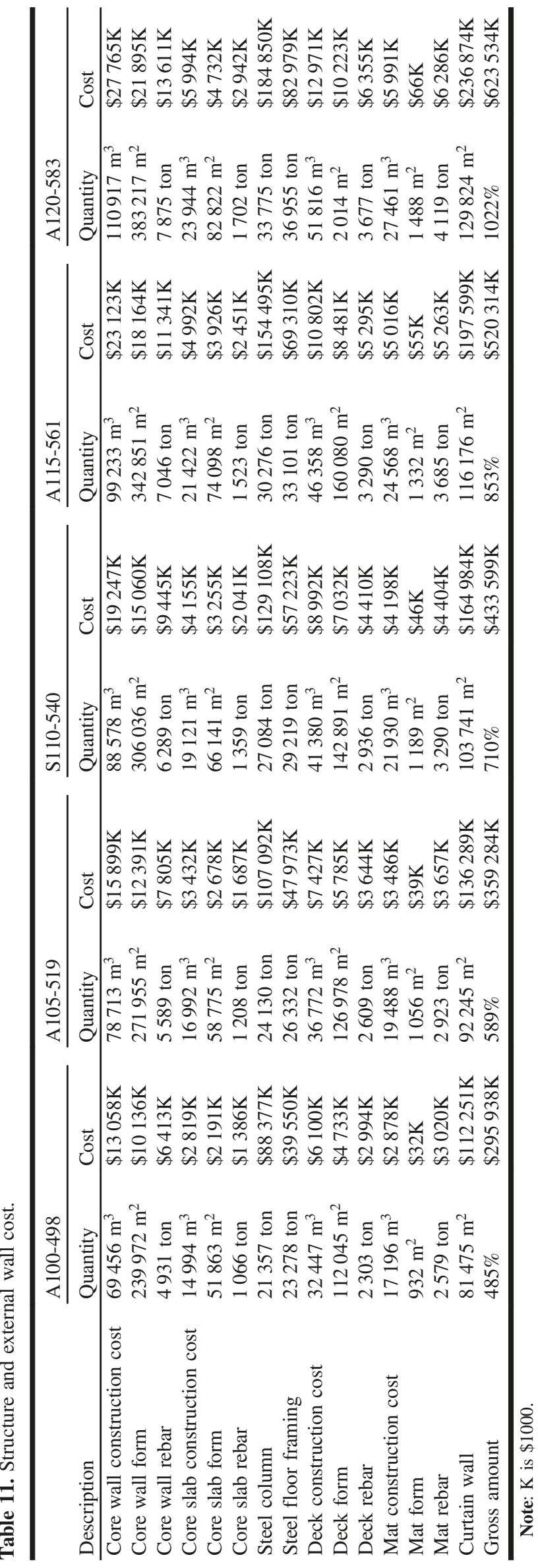

stories (A115-561), 120 stories (A120-583), 125 stories (A125-604), and 130 stories (A130-625). This comparison also demonstrates that gross floor area is changed as $60 \%$, $69 \%, 78 \%, 89 \%, 100 \%, 112 \%, 125 \%, 1139 \%$, and $154 \%$, respectively.

\subsection{High-rise premium ratio data}

Based on the theoretical framework of the high-rise premium ratio described in section 3 , the high-rise premium ratio can be developed for its four components: the labor hoisting premium ratio, material hoisting premium ratio, productivity premium ratio, and climate premium ratio.

The labor hoisting premium ratio is the ratio of labor hoisting time to daily working time as labor goes up and down by hoist before work, during lunch, and after work (see Table 5). This ratio impacts labor cost.

On the other hand, the material hoisting premium ratio is the ratio of material hoisting time to daily working time as material travels up and down by hoist during daily working time (see Table 6).

The productivity premium ratio is the ratio of working time lost during the day (as a result of productivity reduction in the high-rise exterior workshop, work inefficiency due to few inspector visits, and work ineffectiveness caused by minimal communication between the inspector and the workshop) to daily working time (see Table 7).

Furthermore, Table 8 indicates the non-working day ratios of concrete, tower crane, steel, curtain wall work that result from severe temperature, snow, rain, and (or) wind. These data were collected from the Korea Meteorological Administration (KMA).

The non-working day ratios of concrete and tower crane work, steel work and curtain wall work were used to construct the climate premium ratio, which is the ratio of daily working time lost to daily working time due to severe weather (Table 9).

Finally, the high-rise premium ratio is the sum of the labor hoisting, material hoisting, productivity, and climate premium ratios (see Table 10). This high-rise premium ratio is reflected in the labor costs among the construction costs of super tall building alternatives.

\subsection{Cost simulation data}

The major component of cost simulation is quantity estimation and the local price with high-rise premium ratio.

The floor costs of the case model can be calculated as floor quantity multiplied by the unit cost (i.e., material unit cost, equipment unit cost, and labor unit cost multiplied by high-rise premium ratio). Finally, the floor costs are summarized as gross costs, which are the structure and external wall costs.

Table 11 provides comparisons of the structure and external wall cost of the case models' respective core wall, core slab, steel column, steel floor framing, deck slab, mat foundation, and curtain wall. This structure and external wall cost is determined by applying the high-rise premium ratio varied by change in building height.

Examining the case models' cost data (i.e., floor cost data and gross cost data), a comparison of their respective gross amounts indicates that when the models are changed to 90 
Table 12. Construction cost and ratio (S110-540).

\begin{tabular}{lll}
\hline Description & $\begin{array}{l}\text { Construction } \\
\text { cost }\end{array}$ & $\begin{array}{l}\text { Construction } \\
\text { cost ratio }(\%)\end{array}$ \\
\hline Site work & $\$ 24362 \mathrm{~K}$ & 2.1 \\
Equip. \& temp. facilities & $\$ 53596 \mathrm{~K}$ & 4.6 \\
Structural work & $\$ 268615 \mathrm{~K}$ & 23.2 \\
Curtain wall work & $\$ 164984 \mathrm{~K}$ & 14.2 \\
Finish work & $\$ 176379 \mathrm{~K}$ & 15.2 \\
Mechanical & $\$ 147145 \mathrm{~K}$ & 12.7 \\
Electrical & $\$ 121809 \mathrm{~K}$ & 10.5 \\
Vertical transportation & $\$ 58468 \mathrm{~K}$ & 5.0 \\
Provisional sum & $\$ 29234 \mathrm{~K}$ & 2.5 \\
Overhead and profit & $\$ 114826 \mathrm{~K}$ & 9.9 \\
Gross & $\$ 1159417 \mathrm{~K}$ & 100.0 \\
\hline
\end{tabular}

Note: $\mathrm{K}$ is $\$ 1000$.

stories (A90-454), 95 stories (A95-477), 100 stories (A100498), 105 stories (A105-519), 110 stories (S110-540), 115 stories (A115-561), 120 stories (A120-583), 125 stories (A125-604), and 130 stories (A130-625), the gross amounts vary as $60 \%, 69 \%, 78 \%, 89 \%, 100 \%, 112 \%, 125 \%, 1139 \%$, and $154 \%$, respectively.

After the structure and external wall cost of S110-540 is determined, the construction cost can subsequently be estimated. Table 12 shows the construction costs and ratios of S110-540's respective site work, equipment and temporary facilities, structural work, curtain wall, finish work, mechanical work, electrical work, vertical transportation, provisional sum, overhead, and profit. The structure and external wall costs of S110-540 (see Table 11) are equal to structure work and curtain wall work among the construction cost of S110540 (see Table 12).

The construction cost ratio of S110-540 can then be used to estimate the case models' respective construction costs and unit costs. Table 13 indicates the construction costs and unit costs of the nine models. For example, the construction cost and unit cost of A105-519 are $\$ 961928000$ and $\$ 2985 / \mathrm{m}^{2}$, respectively.

Table 14 indicates the gross floor area ratio of the case model. The italicized cells indicate zero percentages for the base model, the above bolded cells are positive percentages that indicate an increasing rate of gross floor area (i.e., +5 stories), and the below bolded cells are negative percentages indicating a decreasing rate of gross floor area (i.e., -5 stories).

For example, if S110-540 (base model) is changed to A115-561, the gross floor area of A115-561 will be increased by $12.03 \%$ of the gross floor area of S110-540. If S110-540 is changed to A105-519, the gross floor area of A105-519 will be decreased by $-11.14 \%$ of the gross floor area of S110-540.

To summarize, the gross floor area ratios of the case models will decrease within the range of $15.17 \%$ to $10.92 \%$ every time an additional 5 floors are added from A90-454 to A130625. Conversely, these will be decreased, within the range from $-9.85 \%$ to $-13.17 \%$, when five floors are deducted from the models A130-625 to A90-454.

Table 15 indicates the construction cost ratios of the case models.

If $\mathrm{S} 110-540$ (base model) is changed to A115-561, the construction cost of A115-561 will be increased by $20.08 \%$ of that of S110-540. And if S110-540 is changed to A105519, the construction cost of A105-519 will be decreased by $-17.03 \%$ of that of S110-540.

In total, the construction cost ratios of the case models decrease from $23.07 \%$ to $18.97 \%$, when five floors are added to the models A90-454 to A130-625. Conversely, when five floors are deducted from the models from A130-625 to A90454 , the construction cost ratios are decreased from $-15.94 \%$ to $-18.75 \%$.

Table 16 indicates the unit cost ratios of the case models.

If S110-540 (base model) is changed to A115-561, the unit cost of A115-561 will increase by $7.18 \%$ of S110-540. If S110-540 is changed to A105-519, the unit cost of A105519 will be decreased by $-6.64 \%$ of S110-540.

To summarize, the unit cost ratios of the case models will increase from $6.86 \%$ to $7.25 \%$, when five floors are added, respectively, to the models A90-454 to A130-625. Conversely, these ratios will decrease from $-6.76 \%$ to $-6.42 \%$, when five floors are deducted from A130-625 to A90-454.

Conversely, these gross floor area, construction cost, and unit cost ratios can be used to predict the construction cost of super tall building's diverse alternatives by changing the number of building stories (i.e., $\pm 5, \pm 10, \pm 15, \pm 20$ stories).

\section{Conclusion}

To reduce the inherent financial risks of super tall building construction, an effective cost estimating tool must be developed. Traditional cost estimating practices (TCEP) have the following limitations: (1) quantity surveyors are required to estimate construction cost during the design development (DD) phase, even though it is necessary for owners to know construction cost during the schematic design (SD) phase to make effective project-related decisions; and (2) if an owner decides to change the number of building stories to reduce discrepancy between construction cost and the project budget, TCEP cannot predict the construction costs of design alternatives because they do not integrate a simulation mechanism. Therefore, this study proposed a schematic cost estimating model (SCEM) that not only addresses these limitations, but that can also be used to estimate the cost of building alternatives for super tall buildings.

First, a theoretical basis for the SCEM was presented. Second, the SCEM was practically implemented by identifying and analyzing the dominant factors that affect construction cost. These factors were then used to develop the high-rise premium ratio, which can be utilized to calculate the productivity ratios of super tall buildings. Using a simulation mechanism, the SCEM estimates construction cost while taking the number of building stories into account. Validation of the SCEM through a case study of a Korean super tall building demonstrated that it could potentially yield financial benefits for owners by facilitating efficient and accurate cost estimation during the SD phase.

Ultimately, this research provides a foundational step toward the development of a more time and cost effective cost estimation model. However, the SCEM still requires improvements to be extensively utilized. Further research should be conducted to determine the materials and equipment that affect construction cost and how these factors vary according 
Table 13. Construction cost.

\begin{tabular}{|c|c|c|c|c|c|c|c|c|c|c|}
\hline \multirow[b]{2}{*}{ Description } & \multicolumn{2}{|l|}{ A100-498 } & \multicolumn{2}{|l|}{ A105-519 } & \multicolumn{2}{|l|}{ S110-540 } & \multicolumn{2}{|l|}{ A115-561 } & \multicolumn{2}{|l|}{ A120-583 } \\
\hline & Cost & $\begin{array}{l}\text { Unit cost } \\
\left(\$ / \mathrm{m}^{2}\right)\end{array}$ & Cost & Unit cost & Cost & Unit cost & Cost & Unit cost & Cost & Unit cost \\
\hline Site Work & $\$ 16809 \mathrm{~K}$ & $\$ 59$ & $\$ 20318 \mathrm{~K}$ & $\$ 63$ & $\$ 24362 \mathrm{~K}$ & $\$ 67$ & $\$ 29150 \mathrm{~K}$ & $\$ 72$ & $\$ 34774 \mathrm{~K}$ & $\$ 77$ \\
\hline $\begin{array}{l}\text { Construction equipments } \\
\& \text { temporary facilities }\end{array}$ & $\$ 36650 \mathrm{~K}$ & $\$ 129$ & $\$ 44493 \mathrm{~K}$ & $\$ 138$ & $\$ 53596 \mathrm{~K}$ & $\$ 148$ & $\$ 64390 \mathrm{~K}$ & $\$ 159$ & $\$ 77149 \mathrm{~K}$ & $\$ 170$ \\
\hline Structure work & $\$ 183687 \mathrm{~K}$ & $\$ 646$ & $\$ 222995 \mathrm{~K}$ & $\$ 692$ & $\$ 268615 \mathrm{~K}$ & $\$ 741$ & $\$ 322715 \mathrm{~K}$ & $\$ 794$ & $\$ 386660 \mathrm{~K}$ & $\$ 852$ \\
\hline Curtain wall & $\$ 112251 \mathrm{~K}$ & $\$ 395$ & $\$ 136289 \mathrm{~K}$ & $\$ 423$ & $\$ 164984 K$ & $\$ 455$ & $\$ 197599 \mathrm{~K}$ & $\$ 486$ & $\$ 236874 \mathrm{~K}$ & $\$ 522$ \\
\hline Finish work & $\$ 120613 \mathrm{~K}$ & $\$ 424$ & $\$ 146424 K$ & $\$ 454$ & $\$ 176379 \mathrm{~K}$ & $\$ 486$ & $\$ 211902 \mathrm{~K}$ & $\$ 522$ & $\$ 253890 \mathrm{~K}$ & $\$ 559$ \\
\hline Mechanical & $\$ 100622 \mathrm{~K}$ & $\$ 354$ & $\$ 122155 \mathrm{~K}$ & $\$ 379$ & $\$ 147145 \mathrm{~K}$ & $\$ 406$ & $\$ 176780 \mathrm{~K}$ & $\$ 435$ & $\$ 211809 \mathrm{~K}$ & $\$ 467$ \\
\hline Electrical & $\$ 83296 \mathrm{~K}$ & $\$ 293$ & $\$ 101121 \mathrm{~K}$ & $\$ 314$ & $\$ 121809 \mathrm{~K}$ & $\$ 336$ & $\$ 146341 \mathrm{~K}$ & $\$ 360$ & $\$ 175339 \mathrm{~K}$ & $\$ 386$ \\
\hline Vertical transportation & $\$ 39982 \mathrm{~K}$ & $\$ 141$ & $\$ 48538 \mathrm{~K}$ & $\$ 151$ & $\$ 58468 \mathrm{~K}$ & $\$ 161$ & $\$ 70244 \mathrm{~K}$ & $\$ 173$ & $\$ 84163 \mathrm{~K}$ & $\$ 185$ \\
\hline Provisional sum & $\$ 19991 \mathrm{~K}$ & $\$ 70$ & $\$ 24269 \mathrm{~K}$ & $\$ 75$ & $\$ 29234 \mathrm{~K}$ & $\$ 81$ & $\$ 35122 \mathrm{~K}$ & $\$ 86$ & $\$ 42081 \mathrm{~K}$ & $\$ 93$ \\
\hline Sub-total & $\$ 713902 \mathrm{~K}$ & $\$ 2511$ & $\$ 866603 \mathrm{~K}$ & $\$ 2690$ & $\$ 1044590 \mathrm{~K}$ & $\$ 2881$ & $\$ 1254244 \mathrm{~K}$ & $\$ 3088$ & $\$ 1502739 \mathrm{~K}$ & $\$ 3310$ \\
\hline Overhead and profit & $\$ 78522 \mathrm{~K}$ & $\$ 276$ & $\$ 95325 \mathrm{~K}$ & $\$ 296$ & $\$ 114826 \mathrm{~K}$ & $\$ 317$ & $\$ 137953 \mathrm{~K}$ & $\$ 340$ & $\$ 165288 \mathrm{~K}$ & $\$ 364$ \\
\hline Gross amount & $\$ 792423 \mathrm{~K}$ & $\$ 2787$ & $\$ 961928 \mathrm{~K}$ & $\$ 2985$ & $\$ 1159417 \mathrm{~K}$ & $\$ 3198$ & $\$ 1392196 \mathrm{~K}$ & $\$ 3427$ & $\$ 1668026 \mathrm{~K}$ & $\$ 3674$ \\
\hline
\end{tabular}

Note: $\mathrm{K}$ is $\$ 1000$.

Table 14. Gross floor area ratio.

\begin{tabular}{|c|c|c|c|c|c|c|c|c|c|}
\hline Model codes & A90-454 & A95-477 & A100-498 & A105-519 & S110-540 & A115-561 & A120-583 & A125-604 & A130-625 \\
\hline Gross floor area & $217136 \mathrm{~m}^{2}$ & $250082 \mathrm{~m}^{2}$ & $284309 \mathrm{~m}^{2}$ & $322201 \mathrm{~m}^{2}$ & $362579 \mathrm{~m}^{2}$ & $406195 \mathrm{~m}^{2}$ & $454019 \mathrm{~m}^{2}$ & $504547 \mathrm{~m}^{2}$ & $559655 \mathrm{~m}^{2}$ \\
\hline A90-454 & $0.00 \%$ & $15.17 \%$ & $30.94 \%$ & $48.39 \%$ & $66.98 \%$ & $87.07 \%$ & $109.09 \%$ & $132.36 \%$ & $157.74 \%$ \\
\hline A95-477 & $-13.17 \%$ & $0.00 \%$ & $13.69 \%$ & $28.84 \%$ & $44.98 \%$ & $62.42 \%$ & $81.55 \%$ & $101.75 \%$ & $123.79 \%$ \\
\hline A100-498 & $-23.63 \%$ & $-12.04 \%$ & $0.00 \%$ & $13.33 \%$ & $27.53 \%$ & $42.87 \%$ & $59.69 \%$ & $77.46 \%$ & $96.85 \%$ \\
\hline A105-519 & $-32.61 \%$ & $-22.38 \%$ & $-11.76 \%$ & $0.00 \%$ & $12.53 \%$ & $26.07 \%$ & $40.91 \%$ & $56.59 \%$ & $73.70 \%$ \\
\hline S110-540 & $-40.11 \%$ & $-31.03 \%$ & $-21.59 \%$ & $-11.14 \%$ & $0.00 \%$ & $12.03 \%$ & $25.22 \%$ & $39.16 \%$ & $54.35 \%$ \\
\hline A115-561 & $-46.54 \%$ & $-38.43 \%$ & $-30.01 \%$ & $-20.68 \%$ & $-10.74 \%$ & $0.00 \%$ & $11.77 \%$ & $24.21 \%$ & $37.78 \%$ \\
\hline A120-583 & $-52.17 \%$ & $-44.92 \%$ & $-37.38 \%$ & $-29.03 \%$ & $-20.14 \%$ & $-10.53 \%$ & $0.00 \%$ & $11.13 \%$ & $23.27 \%$ \\
\hline A125-604 & $-56.96 \%$ & $-50.43 \%$ & $-43.65 \%$ & $-36.14 \%$ & $-28.14 \%$ & $-19.49 \%$ & $-10.01 \%$ & $0.00 \%$ & $10.92 \%$ \\
\hline A130-625 & $-61.20 \%$ & $-55.31 \%$ & $-49.20 \%$ & $-42.43 \%$ & $-35.21 \%$ & $-27.42 \%$ & $-18.88 \%$ & $-9.85 \%$ & $0.00 \%$ \\
\hline
\end{tabular}


Table 15. Construction cost ratio.

\begin{tabular}{|c|c|c|c|c|c|c|c|c|c|}
\hline Model codes & A90-454 & A95-477 & A100-498 & A105-519 & S110-540 & A115-561 & A120-583 & A125-604 & A130-625 \\
\hline $\begin{array}{l}\text { Construction } \\
\text { Cost }\end{array}$ & $\$ 529828 \mathrm{~K}$ & $\$ 652060 \mathrm{~K}$ & $\$ 792423 \mathrm{~K}$ & $\$ 961928 \mathrm{~K}$ & $\$ 1159417 \mathrm{~K}$ & $\$ 1392196 \mathrm{~K}$ & $\$ 1668026 \mathrm{~K}$ & $\$ 1987910 \mathrm{~K}$ & $\$ 2364985 \mathrm{~K}$ \\
\hline A90-454 & $0.00 \%$ & $23.07 \%$ & $49.56 \%$ & $81.55 \%$ & $118.83 \%$ & $162.76 \%$ & $214.82 \%$ & $275.20 \%$ & $346.37 \%$ \\
\hline A95-477 & $-18.75 \%$ & $0.00 \%$ & $21.53 \%$ & $47.52 \%$ & $77.81 \%$ & $113.51 \%$ & $155.81 \%$ & $204.87 \%$ & $262.69 \%$ \\
\hline A100-498 & $-33.14 \%$ & $-17.71 \%$ & $0.00 \%$ & $21.39 \%$ & $46.31 \%$ & $75.69 \%$ & $110.50 \%$ & $150.86 \%$ & $198.45 \%$ \\
\hline A105-519 & $-44.92 \%$ & $-32.21 \%$ & $-17.62 \%$ & $0.00 \%$ & $20.53 \%$ & $44.73 \%$ & $73.40 \%$ & $106.66 \%$ & $145.86 \%$ \\
\hline S110-540 & $-54.30 \%$ & $-43.76 \%$ & $-31.65 \%$ & $-17.03 \%$ & $0.00 \%$ & $20.08 \%$ & $43.87 \%$ & $71.46 \%$ & $103.98 \%$ \\
\hline A115-561 & $-61.94 \%$ & $-53.16 \%$ & $-43.08 \%$ & $-30.91 \%$ & $-16.72 \%$ & $0.00 \%$ & $19.81 \%$ & $42.79 \%$ & $69.87 \%$ \\
\hline A120-583 & $-68.24 \%$ & $-60.91 \%$ & $-52.49 \%$ & $-42.33 \%$ & $-30.49 \%$ & $-16.54 \%$ & $0.00 \%$ & $19.18 \%$ & $41.78 \%$ \\
\hline A125-604 & $-73.35 \%$ & $-67.20 \%$ & $-60.14 \%$ & $-51.61 \%$ & $-41.68 \%$ & $-29.97 \%$ & $-16.09 \%$ & $0.00 \%$ & $18.97 \%$ \\
\hline A130-625 & $-77.60 \%$ & $-72.43 \%$ & $-66.49 \%$ & $-59.33 \%$ & $-50.98 \%$ & $-41.13 \%$ & $-29.47 \%$ & $-15.94 \%$ & $0.00 \%$ \\
\hline
\end{tabular}

Note: $\mathrm{K}$ is $\$ 1000$.

Table 16. Unit cost $\left(\$ / \mathrm{m}^{2}\right)$ ratio.

\begin{tabular}{|c|c|c|c|c|c|c|c|c|c|}
\hline Model codes & A90-454 & A95-477 & A100-498 & A105-519 & S110-540 & A115-561 & A120-583 & A125-604 & A130-625 \\
\hline Unit cost & $\$ 2440$ & $\$ 2607$ & $\$ 2787$ & $\$ 2985$ & $\$ 3198$ & $\$ 3427$ & $\$ 3674$ & $\$ 3940$ & $\$ 4226$ \\
\hline A90-454 & $0.00 \%$ & $6.86 \%$ & $14.23 \%$ & $22.35 \%$ & $31.05 \%$ & $40.46 \%$ & $50.57 \%$ & $61.47 \%$ & $73.18 \%$ \\
\hline A95-477 & $-6.42 \%$ & $0.00 \%$ & $6.90 \%$ & $14.50 \%$ & $22.64 \%$ & $31.45 \%$ & $40.90 \%$ & $51.11 \%$ & $62.07 \%$ \\
\hline A100-498 & $-12.45 \%$ & $-6.45 \%$ & $0.00 \%$ & $7.11 \%$ & $14.73 \%$ & $22.97 \%$ & $31.81 \%$ & $41.36 \%$ & $51.61 \%$ \\
\hline A105-519 & $-18.27 \%$ & $-12.67 \%$ & $-6.64 \%$ & $0.00 \%$ & $7.11 \%$ & $14.80 \%$ & $23.06 \%$ & $31.97 \%$ & $41.54 \%$ \\
\hline S110-540 & $-23.69 \%$ & $-18.46 \%$ & $-12.84 \%$ & $-6.64 \%$ & $0.00 \%$ & $7.18 \%$ & $14.89 \%$ & $23.21 \%$ & $32.15 \%$ \\
\hline A115-561 & $-28.81 \%$ & $-23.93 \%$ & $-18.68 \%$ & $-12.89 \%$ & $-6.70 \%$ & $0.00 \%$ & $7.19 \%$ & $14.96 \%$ & $23.29 \%$ \\
\hline A120-583 & $-33.58 \%$ & $-29.03 \%$ & $-24.14 \%$ & $-18.74 \%$ & $-12.96 \%$ & $-6.71 \%$ & $0.00 \%$ & $7.24 \%$ & $15.02 \%$ \\
\hline A125-604 & $-38.07 \%$ & $-33.82 \%$ & $-29.26 \%$ & $-24.23 \%$ & $-18.84 \%$ & $-13.01 \%$ & $-6.75 \%$ & $0.00 \%$ & $7.25 \%$ \\
\hline A130-625 & $-42.26 \%$ & $-38.30 \%$ & $-34.04 \%$ & $-29.35 \%$ & $-24.33 \%$ & $-18.89 \%$ & $-13.06 \%$ & $-6.76 \%$ & $0.00 \%$ \\
\hline
\end{tabular}


to number of building stories. After further enhancements, it is anticipated that the SCEM will support effective and economical decision-making during the SD phase of super tall buildings.

\section{References}

Abdelhamid, T., and Everett, J. 1999. Time series analysis for construction productivity experiments. Journal of Architectural Engineering, 125(2): 87-95.

Bakewell, R.D. et al. 1999. Skills and Knowledge of Cost Engineering fourth edition, AACE, pp. 1.1-2.8.

Ho, P.H.K. 2007. Economics planning of super tall buildings in Asia Pacific cities. FIG Working Week 2007, Hong Kong SAR, China, http://www.fig.net/pub/fig2007/papers/ts_4g/ts04g_01_ho_1673. pdf (accessed 9 February 2009).

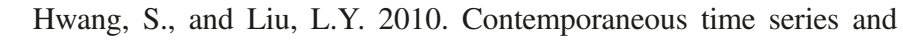
forecasting methodologies for predicting short-term productivity. Journal of Construction Engineering and Management, 136(9): 1047-1055. doi:10.1061/(ASCE)CO.1943-7862.0000183.

-Jrade, A., and Alkass, S. 2007. Computer-integrated system for estimating the costs of building projects. Journal of Architectural Engineering, 13(4): 205-223. doi:10.1061/(ASCE)1076-0431 (2007)13:4(205).

Oberlender, G.D., and Trost, S.M. 2001. Predicting accuracy of early cost estimates based on estimate quality. Journal of Construction Engineering and Management, 127(3): 173-182. doi:10.1061/ (ASCE)0733-9364(2001)127:3(173).
Portas, J., and AbouRizk, S. 1997. Neural network model for estimating construction productivity. Journal of Construction Engineering and Management, 123(4): 399-410. doi:10.1061/ (ASCE)0733-9364(1997)123:4(399).

Seeley, I.H. 1996. Building economics. 4th ed. Macmillan, London, UK.

Shaheen, A., Fayek, A., and Abourizk, S. 2007. Fuzzy numbers in cost range estimating. Journal of Construction Engineering and Management, 133(4): 325-334. doi:10.1061/(ASCE)0733-9364 (2007)133:4(325).

-Song, L., and AbouRizk, S. 2008. Measuring and modeling labor productivity using historical data. Journal of Construction Engineering and Management, 134(10): 786-794. doi:10.1061/ (ASCE)0733-9364(2008)134:10(786).

Sonmez, R. 2008. Parametric range estimating of building costs using regression models and bootstrap. Journal of Construction Engineering and Management, 134(12): 1011-1016. doi:10. 1061/(ASCE)0733-9364(2008)134:12(1011).

- Touran, A. 2003. Probabilistic model for cost contingency. Journal of Construction Engineering and Management, 129(3): 280-284. doi:10.1061/(ASCE)0733-9364(2003)129:3(280).

-Yu, W., and Skibniewski, M. 2010. Integrating neurofuzzy system with conceptual cost estimation to discover cost-related knowledge from residential construction projects. Journal of Computing in Civil Engineering, 24(1): 35-44. doi:10.1061/(ASCE)0887-3801 (2010)24:1(35). 
This article has been cited by:

1. Jong-San Lee, Hyun-Soo Lee, Moon-Seo Park, Sae-Hyun Ji. 2012. A decision support system for super tall building development : DSS FRAMEWORK FOR SUPER TALL BUILDING DEVELOPMENT. The Structural Design of Tall and Special Buildings n/a. [CrossRef]

2. Jong-San Lee, Hyun-Soo Lee, Moon-Seo Park, Sae-Hyun Ji. 2012. A decision support system for super tall building development. The Structural Design of Tall and Special Buildings n/a-n/a. [CrossRef] 